\title{
SOLUȚIONAREA DISPUTELOR
}

\author{
IONEL NARIT,A \\ Universitatea de Vest din Timişoara \\ ionel.narita@gmail.com
}

Title: "Disputes Resolution"

Abstract: By „dispute” we mean an argumentative dialog where each of the two parts state opposite theses. Two sentences can be contrary if they have similar reference, but incompatible predicates (SIP - sentences with incompatible predicates). Usually, the disputes are solved using force in different ways, but that does not mean that the winner is right and his thesis is true. Therefore, we cannot evaluate a thesis on the ground of its success, but we need a reference mark for that. According to the Sophist school, the individual is the only reference mark, so any SIP is equally justified. The absolutist point of view claims that there is an objective reference mark and, consequently, the truth is, at its turn, objective and unique. Finally, the relativist orientation rejects any objective reference mark, but the right thesis is not arbitrary, as the sophists thought, it is true relatively to the state of the evaluator to a given moment. It follows that, for any evaluator, at a moment of time, only one SIP is true.

Keywords: dispute; dialog; argumentation; relativity;

Argumentările sunt simple sau complexe. Printr-o argumentare simplă, locutorul susține sau respinge o singură teză, apelând la un argument și invocând relația dintre argument și teză. Argumentarea complexă conține mai multe teze, dintre care unele sunt principale, altele sunt secundare, ori unele sunt susținute și altele respinse. La rândul lor, argumentările complexe se deosebesc după cum, în dezvoltarea argumentării, intervine sau nu interlocutorul. Argumentarea unde interlocutorul nu adaugă nimic fiind dezvoltată doar de către locutor, se numește monolog argumentativ. Locutorul alege o teză principală și construiește o argumentare complexă, luându-și măsuri de protecție împotriva unor eventuale obiecții pe care le-ar putea ridica un interlocutor critic sau întărind propriile argumente.

Dacă interlocutorul participă la argumentare, punând întrebări, solicitând noi argumente sau completări, ridicând obiecții, formulând contraargumentări sau chiar argumentări proprii etc., vorbim de un dialog argumentativi ${ }^{1}$. Dialogul concordant sau constructiv reprezintă o interacțiune între locutor și interlocutor în care cei doi se află în acord privind o teză sau alta, interlocutorul

${ }^{1}$ Douglas Walton, John Benjamins, Dialog Theory for Critical Argumentation, Amsterdam, 2007, p. 20. 
nu face decât să întărească teza locutorului sau să formuleze noi argumente în sprijinul acelei teze ${ }^{2}$. În schimb, în cazul dialogului discordant sau distructiv interlocutorul se opune tezei locutorului sau, mai general, susține o teză contrară ${ }^{3}$.

După scopul său, dialogul discordant îmbracă forma disputei $i^{4}$ sau a dezbaterii ${ }^{5}$. Prin dispută, înțelegem un dialog în care locutorul și interlocutorul susțin teze opuse căutând să se convingă ${ }^{6}$ unul pe altul cu privire la justețea punctului propriu de vedere. În cadrul dezbaterii, cei doi participanți nu urmăresc să se convingă reciproc, ci sunt indiferenți unul la credințele celuilalt, aceștia au drept scop să convingă membrii unui public că au dreptate. De această dată, ceea ce interesează sunt trăirile și stările emoționale ale unui public de la care se așteptă un anumit comportament, cum ar fi să adere la o cauză sau să voteze cu un candidat oarecare etc.

Cei doi participanți angrenați într-o dispută, locutorul și interlocutorul, susțin teze ${ }^{7}$ opuse, adică susțin propoziții care nu pot fi adevărate împreună. Dacă tezele ar putea avea loc în aceleași împrejurări, înseamnă că pot exista contexte în care ambii să aibă dreptate. Cei doi pot stinge disputa invocând asemenea contexte și, în acest fel, se poate realiza consensul. Mai este posibilă situația în care opoziția să fie aparentă, când cei doi au doar impresia că se află pe poziții ireconciliabile. Soluția poate fi o analiză mai atentă a tezelor susținute, o redefinire a termenilor, clarificarea figurilor semantice sau o reevaluare a referinței propozițiilor implicate.

Dacă notăm locutorul prin $L$ și interlocutorul prin $R$, opoziția apare atunci când:

1) $L$ susține teza $p$ și

1.1. $R$ susține o contrară a lui $p$ sau

1.2. $R$ susţine o contradictorie sau

1.3. $R$ respinge o subalternă a propoziției $p$.

De exemplu, $L$ susține că România este o democrație, pe când $R$ argumentează contrara România este o dictatură sau contradictoria România nu este o democraţie. Opoziția este prezentă și atunci când $R$ respinge consecința că, în România, principiul separației puterilor este respectat.

2) $L$ respinge teza $p$ și

2.1. $R$ susține o supraalternă a lui $p$ sau

2.2. $R$ respinge o subcontrară sau

2.3. $R$ respinge o contradictorie față de teza locutorului.

De exemplu, $L$ ar putea respinge că în România puterea juridică este independentă. $R$ poate replica susținând supraalterna că România este o democrație autentică sau respingând subcontrara că judecătorii sunt cenzurați de instituții ale statului. De asemenea, $R$ ar putea susține negația tezei.

\footnotetext{
${ }^{2}$ Ibidem, p. 96.

${ }^{3}$ Ibidem., p. 20.

${ }^{4}$ Ibidem, p. 25.

${ }^{5}$ Ibidem.

${ }^{6}$ Ibidem, p. 65.

${ }^{7}$ Ibidem, p. 97.
} 
În ultimă instanță, toate aceste cazuri se reduc la situația (1.1) când cei doi susțin teze contrare. Cazul (1.2) este o specie a lui (1.1) deoarece contradictoria este și contrară, prin urmare, a susține negația unei propoziții înseamnă a susține o contrară a ei. În situația (1.3), interlocutorul respinge o subalternă, adică susține negația subalternei. Totodată, negația subalternei este contrara, deci și de această dată $R$ susține o contrară față de $L$.

Dacă $L$ respinge propoziția $p$, înseamnă că susține negația acesteia, respectiv, susține $p^{*}$. Negația supraalternei lui $p$ este subalternă față de $\mathrm{p}^{*}$, prin urmare, supraalterna propoziției $p$ este contrară față de $\mathrm{p}^{*}$. Prin urmare, interlocutorul, susținând o supraalternă a lui $p$, susține o contrară față de $\mathrm{p}^{*}$, din nou, cei doi susțin propoziții contrare. Subcontrara lui $p$ este consecință a negației propoziției $p$. Dacă $R$ respinge subcontrara, înseamnă că susține o negație a subcontrarei dar, negația subcontrarei lui $p$ este contrară față de $\mathrm{p}^{*}$, astfel că și de această dată, cei doi participanți la dispută susțin propoziții contrare. Contradictoria este o subcontrară, prin urmare, (2.3) se reduce la precedentul.

Am obținut că doi interlocutori se află în dispută dacă susțin propoziții contrare. Două propoziții sunt contrare dacă nu respectă principiul noncontradicției care, de fapt, ar trebui numit principiul contrarietăţii deoarece ne spune că o propoziție și negația ei sunt contrare, respectiv, o propoziție și negația ei nu pot fi ambele adevărate în același context. Negația contrarei unei propoziții este subalternă față de acea propoziție. Prin urmare, dacă o propoziția și o contrară a ei ar fi adevărate într-un context, ar urma că atât contrara cât și negația contrarei ar fi adevărate în acel context, contrar principiului amintit. Prin urmare, nu se poate ca atât locutorul cât și interlocutorul să aibă dreptate dacă aceștia susțin propoziții contrare. În acest fel, apar două probleme legate de dispută, cum recunoaștem propozițiile contrare şi cum stabilim cine are dreptate?

Două propoziții elementare, de forma $F x$ și $G y$ pot fi contrare dacă au aceeași referință și dacă predicatele lor sunt incompatibile. De exemplu, „a este mama lui $b$ "și ,a este sora lui $b$ " sunt incompatibile deoarece nimeni nu poate fi atât mamă cât și soră faţă de altul. Dacă asemenea propoziții ar avea referințe diferite, nu este exclus să fie adevărate împreună.

Propozițiile compuse pot fi analizate în propoziții elementare utilizând disjuncția, conjuncția și negația. Contrara oricărei componente a unei conjuncții este contrară față de conjuncție. De pildă, dacă $p$ și $r$ sunt contrare, atunci p\&q este contrară față de $r$. De aceea, pentru a respinge o conjuncție este suficient să respingem un termen al acesteia. Disjuncția poate fi respinsă doar dacă îi respingem toți termenii, respectiv, o contrară pentru o disjuncție este conjuncția contrarelor tuturor termenilor disjuncției. De exemplu, pvq admite contrara r\&s unde $r$ este contrară față de $p$, iar $s$ este contrară față de $q$. Contrara negației unei propoziții, $p^{*}$, este o supraalternă a propoziției, cum ar fi p\&q. Dacă aplicăm aceste considerații propozițiilor categorice, obținem că $A$ este contrară față de $E$ și $O$, iar $I$ este contrară față de $E$ cu același subiect și predicat, sub condiția ca aceste propoziții să aibă referință. 
Propozițiile fără referință sunt adevărate sau false în funcție de înțelesul termenilor, respectiv, în funcție de convențiile de limbaj. De aceea, contrarietatea are loc atunci când convențiile presupuse de interpretarea propozițiilor sunt incompatibile. De exemplu, pornind de la legenda că Pegas era un cal înaripat, disputa ar putea apărea între doi interlocutori dintre care unul ar susține că Pegas este un armăsar înaripat, în vreme ce altul ar argumenta că Pegas este o iapă înaripată.

În ultimă instanță, constatăm că disputele erup atunci când cei doi interlocutori atribuie predicate contrare aceluiași subiect, când presupun că unul sau mai multe obiecte satisfac termeni incompatibili între ei. De exemplu, izbucnește o dispută dacă unul susține „Terenul $a$ este al meu”, iar celălalt susține „Terenul $a$ este al meu”; deși pare că susțin același lucru, datorită înțelesului termenului „meu” propozițiile sunt contrare în funcție de cine le rostește. La fel, doi interlocutori dintre care unul afirmă „Electronii sunt particule” iar celălalt susține că „Electronii sunt unde” se pot afla în dispută, deoarece se ajunge la contradicția „Electronul $a$ este atât undă cât și particulă”.

De regulă, disputele se soluționează în funcție de forța celor doi oponenți, nicidecum după argumentele lor sau, altfel spus, argumentele care au câștig de cauză nu au nici o legătură cu tezele susținute. Iese victorioasă partea care folosește mai eficient, după caz, pumnul, ciomagul, sabia, satârul, tancurile, avioanele, mitralierele, rachetele etc., de care dispune sau are mai multă influență asupra poliției, procuraturii ori judecătoriei. Așa se explică de ce diverse organizații cheltuie enorm pentru asemenea mijloace de convingere. În alte situații, câștigă acela care este susținut de mai multe persoane prin vot sau prin alte mijloace.

Dar, din aceea că un participant învinge într-o dispută, nu înseamnă că are dreptate, ci dreptatea este de partea celui a cărui teză este adevărată. Datorită faptului că tezele sunt opuse, sunt posibile următoarele situații: nici o teză nu este adevărată, când nici unul nu are dreptate sau o singură teză este adevărată. După cum am văzut, tezele care duc la dispute sunt cele care au referință comună dar predicate incompatibile. În acest fel, problema dreptății revine la a determina un criteriu după care putem decide asupra adevărului propozițiilor cu predicate incompatibile. Văzând care propoziții sunt adevărate, putem spune cine are dreptate într-o dispută, indiferent dacă acela câștigă sau nu disputa. Cu privire la un asemenea criteriu, există mai multe perspective.

Sofiștii ${ }^{8}$ considerau că propozițiile cu predicate incompatibile nu sunt contrare ${ }^{9}$, putând fi, la fel de bine, adevărate sau false. ${ }^{10}$ De aceea, Protagoras afirma „Omul este măsura tuturor lucrurilor; a celor existente, întrucât există, iar a celor inexistente, întrucât nu există"11, așa că lucrurile nu sunt date oamenilor într-un

\footnotetext{
${ }^{8}$ Anton Dumitriu, Istoria logicii, ediția a II-a, Editura Didactică și Pedagogică, București, 1975, p. 98.

${ }^{9}$ Ibidem.

${ }^{10}$ Bertrand Russell, op. cit., p. 93.

${ }^{11}$ Ibidem.
} 
anumit fel, ci aceștia le atribuie diferite calități. ${ }^{12}$ De aceea, nu putem spune că, într-o dispută, unul sau altul are dreptate, câștigând partea care are capacitatea de a-și susține cu mai multă dibăcie punctul de vedere ${ }^{13}$. În acest sens, există procedee sau metode prin care poți învinge într-o dispută, iar sofiștii pretindeau că sunt în posesia acestora, fiind gata să îi învețe și pe alții ${ }^{14}$ contra unei remunerațiii ${ }^{15}$. Socrate, însă, folosind maieutica, dovedea că oamenii pot fi aduși la consens ${ }^{16}$, prin urmare, există un singur adevăr, la care oricine poate ajunge ${ }^{17}$.

În acest fel, se ajunge la absolutism conform căruia propozițiile care au predicate incompatibile sunt contrare, de aceea, una singură este adevărată ${ }^{18}$. Absolutismul îmbracă cele mai diverse forme. De pildă, Platon întemeiază absolutismul pe presupunerea că există predicate obiective ale lucrurilor, astfel că, diferența de opinii nu are nici o bază, se datorează incapacității oamenilor de a accesa lumea ideilor sau a calităților absolute ${ }^{19}$. Numai unii oameni au posibilitatea de a cunoaște cu adevărat, respectiv, de a ajunge la absolut așa că doar aceștia au dreptate ${ }^{20}$.

$\mathrm{O}$ altă formă de absolutism are un fundament religios. Divinitatea este aceea care deține adevărul absolut și îl face cunoscut oamenilor prin intermediul profeților. Apare problema de a-i deosebi pe profeții mincinoși. Criteriul folosit, prin care putem pune în evidență propoziția adevărată dintre mai multe contrare, este acela al minunilor. Era crezut profetul care era în stare să săvârșească cele mai multe și mai grozave minuni, astfel că se organizau adevărate întreceri între profeți. Irineu, de pildă, ne învață să nu îi credem pe filosofi, ci pe profeți, deoarece aceștia săvârșesc minuni.

Probabil că forma desăvârșită a absolutismului este atinsă de către Hegel ${ }^{21}$. Logica este alcătuită din tautologii care sunt propoziții adevărate pentru oricine, în orice condiții. Cele mai cunoscute tautologii constau în disjuncția dintre o propoziție și negația ei, pvp*. Conform principiilor logicii, doar una dintre acestea are loc într-un context dat. Lumea este constituită din propozițiile care se petrec și care nu sunt tautologii. Dar tautologiile reprezintă adevărul, ceea ce se petrece este doar un adevăr parțial, o cale spre adevărul absolut. Pentru a se realiza adevărul absolut trebuie să aibă loc ambele componente ale unei tautologii. Prin urmare, dacă are loc $p$ trebuie să aibă loc și $p^{* 22}$. Dacă $p$ este teza, atunci $p^{*}$ este antiteza, iar unitatea dintre acestea două și care reprezintă un adevăr de ordin superior este

\footnotetext{
${ }^{12}$ Douglas Walton, John Benjamins, op. cit. , p. 51.

${ }^{13}$ Marius Dobre, Discurs publicitar, retorică, logică, Trei, București, 2017, p. 51.

${ }^{14}$ Anton Dumitriu, op. cit., p. 96.

${ }^{15}$ Bertrand Russell, op. cit., p. 96.

${ }^{16}$ Anton Dumitriu, op. cit., p. 105.

${ }^{17}$ Bertrand Russell, op. cit., p. 99.

${ }^{18}$ Marius Dobre, op. cit., p. 65.

${ }^{19}$ Anton Dumitriu, op. cit., p. 109.

${ }^{20}$ Bertrand Russell, op. cit., p. 143.

${ }^{21}$ Idem, Istoria filosofiei occidentale, II, Humanitas, București, 2005, p. 242.

${ }^{22}$ Anton Dumitriu, op. cit., p. 675.
} 
sinteza $a^{23}$. Realizarea unei sinteze este la rândul ei parțială, se constituie într-o nouă teză care atrage $o$ antiteză ${ }^{24}$ și ajungem la o altă sinteză etc ${ }^{25}$.

Lumea reprezintă doar calea spre realizarea absolutului ${ }^{26}$ care vedem că este unitatea tuturor contrariilor ${ }^{27}$. Pe de altă parte, unitatea contrariilor reprezintă logica, aşa încât, ceea ce se petrece, lumea este în interiorul logicii, este raţionalăa ${ }^{28}$. În final, există un singur adevăr care este adevărul absolut și care constă în unitatea tuturor contrariilor ${ }^{29}$. Cei care susțin contrarii, care se află în dispută, reprezintă pași necesari către realizarea absolutului, de aceea, disputa, conflictul, războiul sunt necesare și raționale, mai mult decât atât, nu pot fi evitate.

Dacă acceptăm perspectiva absolutistă, trebuie să existe un reper absolut la care să ne raportăm pentru a stabili propoziția adevărată dintre cele cu predicate incompatibile. La un moment dat, oamenii de știință au crezut că au descoperit un asemenea reper cu privire la propozițiile mecanicii, în legătură cu pozițiile și deplasarea corpurilor în spațiu. De exemplu, dacă cineva afirmă „Corpul $a$ este în repaus" iar altul „Corpul $a$ se mișcă", nu este clar cine are dreptate dacă nu există un reper care să fie în repaus absolut. Dacă $a$ se deplasează față de un asemenea reper, atunci al doilea are dreptate, în alt caz, are dreptate primul.

Cercetările asupra luminii au dus la concluzia că ipoteza ondulatorie explică cel mai bine fenomenele de interferență, reflexie sau refracție. Dacă lumina este o undă, trebuie să existe un mediu în care se propagă, iar acest mediu a fost numit eter ${ }^{30}$. Proprietățile luminii impun ca eterul să fie complet imobil, aşa încât, eterul este un reper absolut pentru propozițiile privind mișcarea corpurilor ${ }^{31}$. Dacă am raporta stările corpurilor la eter, am putea spune care se mișcă și care sunt în repaus.

Michelson și Morley au conceput un dispozitiv care, cu ajutorul interferenței luminii, trebuia să dea indicii asupra vitezei Pământului în raport cu eterul ${ }^{32}$. Două raze de lumină, una care se deplasează odată cu Pământul și alta împotriva acestuia, erau trimise în același punct cu ajutorul unor oglinzi, iar experimentul trebuia să pună în evidență o diferență de viteză a acestora ${ }^{33}$. Deși a fost repetat de mai multe ori, experimentul Michelson - Morley a avut un rezultat negativ, cele două raze de lumină nu generau figura de interferență așteptată ${ }^{34}$.

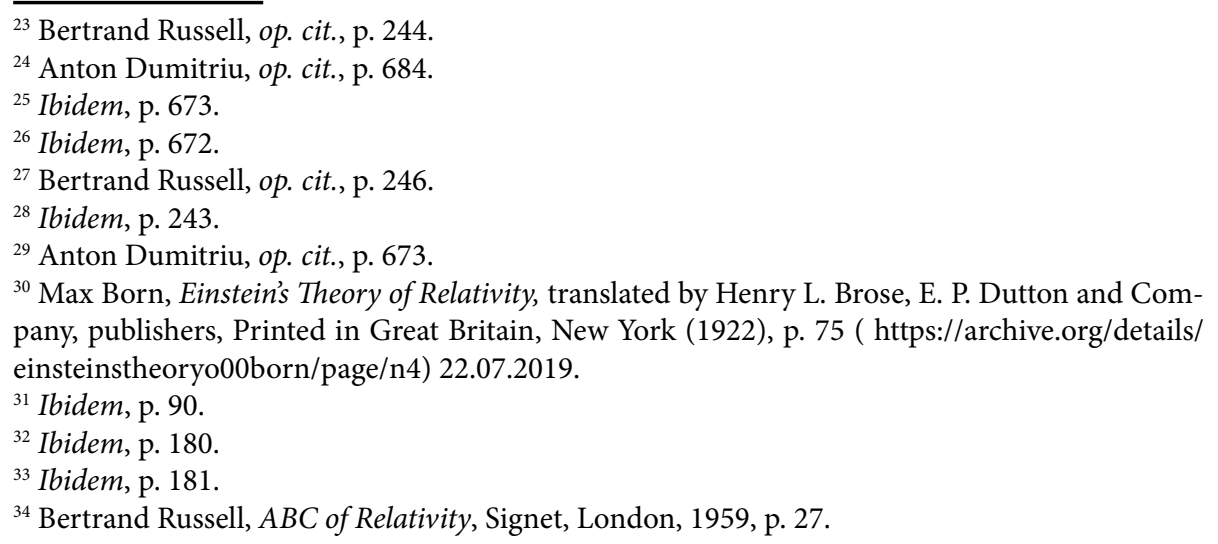


Lorentz a încercat să salveze eterul prin ipoteza fantezistă că dimensiunile corpurilor se modifică atunci când se află în mișcare ${ }^{35}$. Deoarece, în acest fel, distanța parcursă de razele de lumină era diferită, acestea, deși aveau viteze diferite, ajungeau în același timp și nu dădeau nici o figură de interferență, explicând rezultatul negativ al experimentului Michelson - Morley.

Einstein apelează la o altă strategie pentru a da seama de aceleași fapte. El admite corectitudinea rezultatului experimentului, că lumina parcurge aceeași distanță în același interval de timp indiferent de sistemul de referință la care ne raportăm, dacă acesta este inerțial și generalizează acest rezultat, admițând principiul constanței vitezei luminii în raport cu sistemele de referință inerțiale ${ }^{36}$. Einstein dovedește că acest principiu este suficient pentru a da seama de experimentul Michelson Morley.

Dar, dacă viteza luminii nu depinde de sistemul de referință, rezultă că toate reperele relevante pentru propozițiile mecanicii sunt echivalente, prin urmare, nu există reper privilegiat, nu există eter. Dacă nu există reper privilegiat, înseamnă că lumea este așa cum apare relativ la fiecare reper în parte, deci există propoziții cu predicate incompatibile care nu sunt contrare și este posibil ca doi interlocutori care susțin asemenea propoziții să aibă ambii dreptate ${ }^{37}$. Această teză este esența unei alte perspective privind disputele, numită relativism ${ }^{38}$.

Teoriei lui Einstein i s-au adus diverse obiecții, unele juste altele fără importanță. Apărarea că teoria relativității a fost verificată prin experiență este ridicolă, o ipoteză sau o teorie nu pot fi verificate empiric, deoarece au pretenții de universalitate, altfel nu ne-ar ajuta în ce privește explicația, predicția ori acțiunea. Experiența este întotdeauna particulară, nu poate justifica teorii universale. În plus, niciodată antecedentul nu poate fi justificat prin consecvent.

Einstein rezolvă paradoxul Michelson - Morley introducând principiul constanței vitezei luminii în vid, dar un asemenea principiu nu este necesar, așa cum am văzut, paradoxul poate fi eliminat și prin ipoteza lui Lorentz. De fapt, Einstein ajunge la aceleași formule ca și Lorentz, doar că interpretarea lor este diferită. Întregul edificiu a lui Einstein se bazează pe ipoteza că există sisteme de referință inerțiale, altfel principiul constanței vitezei luminii și celelalte raționamente einsteiniene nu ar avea nici o bază. Totuşi, nimeni nu ar fi în stare să indice măcar un singur sistem de referință inerțial, pentru motivul că acestea nu pot să existe. Principiul inerției, așa cum este folosit în fizică după Galilei și Newton nu are nici măcar o singură instanță reală, naturală, făcând din fizică o știință fantezistă ${ }^{39}$. De asemenea, dacă nu există eter, cum explicăm comportamentul undelor luminoase? Einstein revine la teoria corpusculară prin ipoteza fotonilor, dar, ulterior, mecanica cuantică reinventează undele dar fără a mai pomeni nimic de eter.

\footnotetext{
${ }^{35}$ Max Born, op. cit., p. 184.

${ }^{36}$ Ibidem, p. 192.

${ }^{37}$ Douglas Walton, John Benjamins, op. cit. , p. 112.

${ }^{38}$ Bertrand Russell, op. cit., p. 17.

${ }^{39}$ Max Born, op. cit., p. 27.
} 
$\mathrm{Cu}$ toate acestea, concluzia la care ajunge Einstein că nu există reper absolut nu poate fi respinsă. Susținătorii tezei reperului absolut ar trebui să îl indice, odată ce aceștia consideră că există un asemenea reper, ar trebui să precizeze care este acesta, dar niciunul nu a fost în măsură să ni-l arate. Dimpotrivă, absolutiștii după ce au decretat că reperul absolut există l-au plasat în afara lumii, într-un fantomatic domeniu al realității: Platon inventează lumea ideilor ${ }^{40}$, Augustin invocă cetatea lui Dumnezeu, Hegel îl transformă într-un ideal spre care tindem dar niciodată nu îl vom atinge etc. În acest mod, chiar dacă reperul absolut ar exista, nu ne este de nici un folos, odată ce nu avem acces la el, acesta nu poate servi pentru a vedea cine are dreptate.

Desigur, nu poți să combați teza absolutistă deoarece adepții acesteia, plasând reperul absolut în afara lumii și experienței, resping logica sau inventează alte logici. Orice raționament ar fi invocat, vor veni cu logica nouă respingând prăfuita logică clasică. Degeaba i-ai invoca lui Augustin contradicțiile la care duce ipoteza divinității, deoarece va spune că suntem în faţa unui mister de nepătruns. De asemenea, ar fi fără rost să îi atragi atenția unui adept al mecanicii cuantice că nu se poate ca vreo entitate să fie atât undă cât și corpuscul, acestea fiind incompatibile, deoarece va face apel la logica cuantică, unde contrarele nu sunt contradictorii ci sunt complementare! $!^{41}$

Dacă nu există reper absolut, înseamnă că orice evaluator estela fel deîndreptățit în stabilirea valorii de adevăr a propozițiilor și orice interlocutor are dreptate într-o dispută. Dar de aici nu rezultă, aşa cum credeau sofiștii, că ar avea dreptate dacă ar susține orice. Dacă reperul nu este legat de nimic obiectiv deoarece, în alt mod, ar fi absolut, înseamnă că este subiectiv. Cu alte cuvinte, reperul constă în starea în care se află evaluatorul la un moment dat. De aceea, adevărul unei propoziții depinde de evaluator și de timp, când spunem că o tautologie este adevărată în orice context, spunem că este adevărată pentru orice evaluator, în orice moment. De aici rezultă că, pentru un evaluator sunt adevărate acele propoziții care sunt în concordanță cu starea sa. Dacă cineva susține că un corp are $1 \mathrm{~m}$ lungime, iar altul că are 1,2 m lungime, nu înseamnă că unul trebuie să se înșele. S-ar putea ca ambii să aibă dreptate, în funcție de starea în care se găsesc. La fel de bine, nu este exclus ca numai unul să aibă dreptate sau niciunul.

Disputele nu pot fi soluționate invocând un reper obiectiv la care să se raporteze interlocutorii, deoarece orice reper este subiectiv. Propozițiile cu predicate incompatibile sunt contrare doar relativ la starea unui evaluator. Acest fapt rezultă din aceea că pentru un evaluator aflat în stări diferite (la momente diferite) nimic nu împiedică două propoziții cu predicate incompatibile să fie ambele adevărate. De pildă, la un moment dat, s-ar putea să fie adevărat că un corp are $1 \mathrm{~m}$ lungime, iar la alt moment, același corp să aibă $1,2 \mathrm{~m}$ lungime. Dacă avem în vedere doi evaluatori, aceștia se află necesar în stări diferite, prin urmare, este firesc ca pentru fiecare să fie adevărate propoziții cu predicate

\footnotetext{
${ }^{40}$ Bertrand Russell, op. cit., p. 143.

${ }^{41}$ Peter Mittelstaedt, Quantum Logic, Reidel, Dordrecht, 1978, p. 72.
} 
incompatibile diferite. Numai dacă ne raportăm la o singură stare, respectiv, la un evaluator și la un moment determinat, este adevărată una singură dintre propozițiile care au aceeași referință dar predicate contrare.

$\mathrm{Cu}$ toate acestea, consensul este posibil, dar numai relativ, bazat pe principiul toleranței. Dacă doi interlocutori susțin propoziții cu predicate contrare nu înseamnă că ei se află în dezacord. S-ar putea să fie dezacord între interlocutori care susțin aceeași teză. De exemplu, dacă doi interlocutori susțin despre un corp că are $1 \mathrm{~m}$ lungime, cu siguranță, unul se află în eroare sau minte. Un evaluator poate stabili care este propoziția justificată relativ la alt evaluator dacă ține seama de relația față de acesta. Dacă pentru $X$ este adevărată $p$ iar $Y$ se află în relația $R$ față de $X$, atunci pentru $Y$ este adevărată propoziția corespunzătoare acelei relații, conform raționamentului: $X$ este justificat să susțină $p$; $Y$ este în relația $R$ față de $p /$ $Y$ este justificat să susțină $q$.

Primele asemenea relații au fost puse în evidență de către Einstein ${ }^{42}$, fiind cunoscute sub numele de reguli de transformare care diferă fundamental de regulile de transformare ale lui Galilei ${ }^{43}$. Acestea din urmă arată care este viteza unui corp față de un sistem de referință în mișcare, dar viteza lui reală este față de sistemul în repaus. În cazul regulilor de transformare ale lui Einstein, nu este vorba că un corp și-ar modifica dimensiunile de la un reper la altul ci un observator care ar măsura dimensiunile într-un sistem de referință ar ajunge la rezultatul dat de regulile de transformare. Nu există anumite dimensiuni proprii corpului care să se reducă sau să se mărească după starea evaluatorului ci dimensiunile sunt chiar cele măsurate, iar acestea diferă în funcție de starea în care se găsește evaluatorul. Prin urmare, doi interlocutori sunt în consens, respectiv, ambii sunt justificați în ceea ce susțin, dacă tezele lor se află în relația prevăzută de regulile de transformare pentru acea categorie de propoziții și dacă ele coincid ${ }^{44}$.

Aparent, perspectiva relativistă nu explică posibilitatea oamenilor de a coopera între ei. De pildă, să presupunem doi constructori ai turnului Babel dintre care unul este pe schelă, iar celălalt lângă o grămadă de cărămizi. Muncitorul aflat pe schelă îi cere celuilalt să îi aducă o cărămidă de 50/20/10 cm. Examinând cărămizile, muncitorul de lângă stivă va constata că nu există nici o cărămidă la dimensiunile cerute și nu va ști ce să facă, deoarece el evaluează dimensiunile cărămizilor diferit faţă de celălalt.

Asemenea situații sunt soluționate prin adoptarea unui reper convențional, acceptat de către toți membrii unei comunități semiotice. Reperul convențional reprezintă o anumită stare cât mai bine definită față de care să fie examinate lucrurile și cu toții să cadă de acord că propozițiile conforme cu acea stare sunt cele reale. De pildă, un observator care privește tăblia unei mese oblic, o vede ovală, pe când unul care o privește perpendicular, o vede rotundă. Se poate adopta convenția: tăblia mesei este aşa cum este văzută dintr-o perspectivă perpendiculară față de tăblie. În acest fel, cei doi vor cădea de acord că tăblia este rotundă. De aici nu rezultă

${ }^{42}$ Max Born, op. cit., p. 98.

${ }^{43}$ Ibidem, p. 62.

${ }^{44}$ Arno R. Lodder, DiaLaw, Springer, Dordrecht, 1999, p. 11. 
că evaluatorul care o consideră ovală se află în eroare, ci doar că se supune unei convenții prin care cooperarea în interiorul comunității este posibilă. La fel de bine s-ar putea adopta convenția că tăblia este aşa cum este văzută sub un unghi de $45^{\circ}$ etc. Dimensiunile unui corp sunt acelea măsurate în repaus faţă de acesta, iar masa sa este dată de un cântar în repaus față de acel corp. Cu alte cuvinte, caracteristicile obiective ale obiectelor sunt intenționale și convenționale, adică sunt rodul unor acte de comunicare.

Înțelesul termenilor comunicaționali rezultă, la fel, din acte de comunicare. De exemplu, pentru a afla ce drepturi are cineva, trebuie avute în vedere acte comunicaționale de o anumită categorie. Degeaba am investiga empiric situația cuiva pentru că, în privința drepturilor, nu am ajunge la nici o concluzie, oricâte observații sau experimente am face. La fel se întâmplă cu termeni precum „președinte”, „ş̧ef”, „subaltern” etc., pentru a vedea dacă teza „X este șeful lui $Y$ ” este adevărată trebuie să avem în vedere mesajele dintre cei doi, cât și mesajele altor membri ai unei organizaţii ori documentele din cadrul organizaţiei respective.

În cazul tezelor cu predicate comunicaționale, simpla observare a mesajelor nu este suficientă, ci acestea trebuie interpretate. Un text este interpretat printrun alt text pe care interpretul îl considera adevărat în condițiile de adevăr ale textului dat. Textul interpretat este analizat pentru a i se pune în evidență condițiile de adevăr, apoi se elaborează un alt text care să corespundă acestor condiții. $\mathrm{Cu}$ alte cuvinte, pentru a stabili adevărul propozițiilor care au predicate comunicaționale, nu este nevoie să ieșim din text. Adevărul unei propoziții de acest fel depinde doar de mesajul care o conține și de alte texte în relație cu acesta.

Interpretarea ascultă de principiul autonomiei textului. Un text poate fi interpretat indiferent de autor, interpretul nu are nevoie să cunoască intențiile autorului pentru a da o interpretare unui text. De aceea, interpretarea este o relație între interpret și text. Totodată, oricine poate interpreta la fel de bine un text, respectiv, nu există interpret privilegiat. De aceea, disputele în care intervin predicate comunicaționale depind de interpretarea unor texte, dar fiecare ar putea interpreta textele în felul său. De pildă, dacă fiecare dintre doi interlocutori susține că un anumit teren i se cuvine, fiecare poate apela la diferite acte interpretate conform propriului interes.

Să spunem că între doi interlocutori se naște o dispută în care unul susține că barba lui Algazy este susținută de un grătar înșurubat sub bărbie, iar celălalt că grătarul este înşurubat deasupra pieptului. Pentru a stabili cine are dreptate, degeaba l-am căuta pe Algazy pentru a vedea cum este barba acestuia, decizia poate fi luată doar pe baza textului lui Urmuz, Algazy fiind un termen construit comunicațional. Adevărul unor asemenea afirmații nu iese în afara textului, fiind vorba de un adevăr intensional, nu extensional.

Consensul este posibil dacă interlocutorii ajung singuri la o interpretare comună ${ }^{45}$ prin negociere sau sub coordonarea unui mediator, ori apelează la un alt interpret recunoscut de ambele părți, ca arbitru. În alte situații, arbitrajul este impus celor aflați în dispută de către o organizație care urmărește să își protejeze

${ }^{45}$ Douglas Walton, John Benjamins, op. cit., p. 14. 
propriile interese. De această dată, arbitrul va interpreta documentele conform intereselor organizației și nu ale părților și va da o sentință pe baza interpretării obligând părțile să o accepte.

Nu există nici un temei să presupunem că arbitrul sau judecătorul are dreptate, de aceea, este eronat să asociem dreptatea cu actul judecătorului ${ }^{46}$. Acesta este un interpret la fel ca oricare altul, supus unor interese dintre cele mai diverse, atâta doar că este învestit ca interpret recunoscut de către o organizație. Soluționarea disputelor prin intermediul arbitrului sau judecătorului nu este altceva decât o altă formă de utilizare a forței. La fel ca în cazul folosirii ciomagului, nu este exclus ca, în unele cazuri, sentința să fie dreaptă. Cel care câștigă într-o luptă s-ar putea să aibă dreptate, dar nu are dreptate datorită victoriei sale. De asemenea, nu este exclus ca sentința dată de judecător să fie dreaptă, dar, din nou, dreptatea nu se datorează judecătorului, ori judecății.

\section{Bibliografie:}

Born, Max, Einstein's Theory of Relativity, E. P. Dutton \& Co., New York, 1922 Dobre, Marius, Discurs publicitar, retorică, logică, Trei, București, 2017

Dumitriu, Anton, Istoria logicii, Ed. Didactică și Pedagogică, București, 1975

Lodder, Arno R., DiaLaw, Springer, Dordrecht, 1999

Mittelstaedt, Peter, Quantum Logic, Reidel, Dordrecht, 1978

Russell, Bertrand, Istoria filosofiei occidentale, I, Humanitas, București, 2005

Russell, Bertrand, Istoria filosofiei occidentale, II, Humanitas, București, 2005

Russell, Bertrand, ABC of Relativity, Signet, London, 1959

Walton, Douglas, Benjamins, John, Dialog Theory for Critical Argumentation, John Benjamins, Amsterdam, 2007

\section{Webografie:}

https://archive.org/details/einsteinstheoryo00born/page/n4

${ }_{46}$ Arno R. Lodder, DiaLaw, Springer, Dordrecht, 1999, p. 61. 